\title{
Uji in silico Aktivitas Sitotoksik dan Toksisitas Senyawa Turunan $N$-(Benzoil)- $N$ '- feniltiourea Sebagai Calon Obat Antikanker
}

\author{
Dini Kesuma $^{1,2}$, Siswandono ${ }^{1}$, Bambang Tri Purwanto ${ }^{1}$ dan Suko Hardjono ${ }^{1 *}$ \\ ${ }^{1}$ Departemen Kimia Farmasi, Fakultas Farmasi Universitas Airlangga, Surabaya \\ ${ }^{2}$ Departemen Kimia Farmasi, Fakultas Farmasi Universitas Surabaya, Surabaya \\ *email korespondensi: suko-h@ff.unair.ac.id
}

\begin{abstract}
Abstrak: Senyawa $N$-(benzoil)- $N$ '-feniltiourea mempunyai gugus farmakofor yang sama dengan turunan urea yang mempunyai aktivitas antikanker, seperti hidroksiurea, sehingga layak dijadikan senyawa induk untuk dikembangkan lebih lanjut melalui modifikasi struktur. Penelitian ini bertujuan untuk memprediksi aktivitas sitotoksik dan toksisitas dari duapuluh tiga senyawa turunan $N$-(benzoil)- $N$ '-feniltiourea sebagai calon obat antikanker. Salah satu mekanisme kerja turunan $N$-(benzoil)- $N$ '-feniltiourea sebagai antikanker adalah menghambat VEGFR2, regulator penting untuk proses angiogenesis, serta sangat berperan untuk pertumbuhan tumor dan metastasis. Aktivitas biologis dapat diprediksi melalui pemodelan molekul yang disebut uji in silico, menggunakan program MVD (Molegro Virtual Docker), sedang toksisitas dapat diprediksi menggunakan program pkCSM dan Protox online tool. Uji in silico dilakukan dengan melakukan docking senyawa yang akan diprediksi aktivitasnya dengan target reseptor, VEGFR2, PDB ID. 3WZE. Hasil docking berupa energi ikatan digambarkan dengan nilai Rerank Score $(R S)$. Senyawa dengan nilai $R S$ kecil berarti mempunyai ikatan ligan-reseptor yang stabil dan diprediksi mempunyai aktivitas yang besar. Dari hasil uji in silico disimpulkan bahwa semua turunan $N$-(benzoil)- $N$ '-feniltiourea diprediksi menimbulkan toksisitas relatif rendah, dan mempunyai aktivitas sitotoksik lebih besar dibanding hidroksiurea, tetapi masih lebih rendah dibanding sorafenib. $\mathrm{N}$-(4propoksibenzoil)- $N$ '-feniltiourea dan $N$-(3,5-di-trifluorometilbenzoil)- $N$ '-feniltiourea diprediksi mempunyai aktivitas sitotoksik paling besar tetapi menimbulkan hepatotoksik, sehingga sebagai senyawa terpilih untuk disintesis dan dikembangkan lebih lanjut adalah $\mathrm{N}$ (3,4-dimetilbenzoil)-N'-feniltiourea.
\end{abstract}

Kata kunci: Pemodelan molekul; N-(benzoil)-N'-feniltiourea; aktivitas sitotoksik; toksisitas.

\begin{abstract}
In silico test of toxicity and cytotoxic activity from $N$-(Benzoil)- $N$ '- feniltiourea derivatives as anticancer drug candidate. The $N$-(benzoyl)- $N$ '-phenylthiourea compound has the same pharmacophore as some urea derivatives having anticancer activity, such as hydroxyurea, so it can be the parent compound for further derivative development through structure modification. This study was aimed to predict cytotoxic activity and toxicity of twenty-three $N$-(benzoyl)- $N$ '-phenylthiourea derivatives as potential anticancer agents. One of the action mechanisms of $N$-(benzoyl)- $N$ '-phenylthiourea derivatives as anticancer is by inhibiting VEGFR2, a crucial regulator of angiogenesis and is essential for tumor growth
\end{abstract}


and metastasis. The biological activity could be predicted through molecular modeling called in silico test, using MVD (Molegro Virtual Docker) program, while toxicity was predicted using pkCSM and Protox online tool program. In silico test was performed by docking a compound that will predict its activity with target receptor, VEGFR2, PDB ID. 3WZE. The docking result was in the form of bond energy described by Rerank Score (RS). A compound having a small RS value was predicted to have greater activity. From the in silico study, it could be concluded that all of the $N$-(benzoyl)- $N$ '-phenylthiourea derivatives were predicted to cause relatively low toxicity and had greater cytotoxic activity than hydroxyurea, but still lower compared with sorafenib. $N$-(4-propoxybenzoyl)- $N$ '-phenylthiourea and $N$-(3,5-ditrifluoromethylbenzoyl)- $N$ '-phenyl-thiourea was predicted to have the greatest cytotoxic activity, but caused hepatotoxicity, thus the preferred compound to be synthesized and further developed is $\mathrm{N}$ - (3,4-dimethylbenzoyl) -N'-phenylthiourea.

Keywords: Molecular modeling; N-(benzoyl)-N'-phenylthiourea; cytotoxic activity; toxicity

\section{Pendahuluan}

Upaya pengembangan obat yang telah ada dapat dilakukan dengan rancangan obat. Rancangan obat bertujuan untuk mendapatkan obat baru dengan aktivitas yang lebih baik dan mempunyai toksisitas yang lebih rendah dengan melalui modifikasi struktur. Modifikasi struktur dilakukan dengan mensitesis sejumlah turunan senyawa induk, melakukan identifikasi struktur dan melakukan uji aktivitas biologisnya (Siswandono, 2014). Perubahan struktur dari suatu senyawa akan mengubah sifat fisikokimia senyawa, termasuk sifat lipofilik, elektronik dan sterik, dan perubahan sifat fisikokimia ini akan menyebabkan perubahan aktivitas biologis senyawa (Hardjono, 2012; Hardjono dkk, 2016).

Sebelum melakukan sintesis pada modifikasi struktur, diperlukan suatu upaya untuk memprediksi sifat fisikokimia, aktivitas biologis dan toksisitas senyawa yang akan disintesis. Metode yang sekarang sedang dikembangkan adalah pemodelan molekul (Schlick, 2010). Pemodelan molekul yang juga disebut uji in silico yang mempunyai peran yang sangat penting dalam bidang Kimia Medisinal dalam rangka merancang, menemukan dan optimasi senyawa bioaktif pada proses pengembangan obat (Hinchliffe, 2008; Siswandono, 2016).

Cara melakukan uji in silico adalah dengan docking molekul yang akan diprediksi aktivitasnya pada sel target yang dipilih. Docking adalah suatu upaya untuk menselaraskan antara ligan yang merupakan molekul kecil ke dalam sel target yang merupakan molekul protein yang besar (Jensen,2007). Uji in silico menghasilkan nilai energi ikatan atau Rerank Score $(R S)$. Energi ikatan menunjukkan jumlah energi yang dibutuhkan untuk membentuk ikatan antara ligan dengan reseptor. Semakin kecil energi ikatan berarti semakin stabil ikatan tersebut. Semakin stabil ikatan ligan dengan reseptor maka dapat diprediksikan bahwa aktivitasnya juga semakin besar (Hardjono, 2012).

Penyakit kanker yang jumlahnya semakin meningkat telah mendorong dilakukannya pengembangan obat antikanker. Jumlah penderita kanker di dunia mencapai 14,068 juta jiwa. Sebanyak 8,202 juta kematian akibat kanker dan 32,455 juta orang terdiagnosa kanker dalam 5 tahun terakhir. Diperkirakan kanker akan meningkat 14 juta kasus baru dari tahun 2012 sampai 2022 (World Health Organization, 2012).

Tahun 2010 Saeed et al. telah melakukan penelitian turunan tiourea dengan menambahkan gugus benzotiazol dan mendapatkan bahwa beberapa turunan tiourea 
mempunyai aktivitas antikanker pada sel MCF-7 dan sel HeLa. Li et al. pada tahun yang sama telah melakukan penelitian pada turunan $N$-benzil- $N$-(X-2-hidroxibenzil)-NO-feniltiourea yang menunjukkan aktivitas sebagai antikanker payudara. Ada beberapa turunan urea, seperti turunan tienopiridin urea, aminopirazolopiridin urea, dan indenopirazol, bekerja sebagai antikanker dengan cara menghambat reseptor VEGFR2 (Dai et al., 2008; Usui et al., 2008; Curtin et al., 2012).

Ruswanto dkk., pada tahun 2017 telah melakukan penelitian turunan 1-benzoil-3metiltiourea sebagai calon obat antikanker dengan melakukan docking molekul terhadap enzim ribonukleotida reduktase, dan memprediksi absorpsi, distribusi, toksisitas dan aktivitasnya. Hasil penelitian adalah prediksi bahwa turunan tersebut mempunyai aktivitas, absorpsi, dan distribusi yang lebih baik dibanding hidroksiurea, serta mempunyai toksisitas yang relatif rendah.

Nasyanka (2017) telah mensintesis senyawa $N$-benzoil- $N$ '-(4-fluorofenil)tiourea dan tiga turunannya serta menentukan aktivitas sitotoksiknya terhadap sel line MCF 7. Dari penelitian tersebut telah dilakukan uji in silico untuk memprediksi aktivitas sitotoksik empat turunan $\mathrm{N}$ benzoil- $N$ '-(4-fluorofenil)tiourea dengan target enzim Sirtuin-1 kode pdb. 4I5I. Hasil penelitian adalah prediksi bahwa keempat senyawa turunan $N$-benzoil- $N$ '-(4fluorofenil)tiourea mempunyai aktivitas sitotoksik yang lebih besar dibanding senyawa ligan (4I5_601) dan hidroksiurea.

Penelitian ini melakukan uji in silico dari 23 senyawa turunan $N$-(benzoil)- $N$ 'feniltiourea untuk memprediksi aktivitas sitotoksiknya terhadap enzim VEGFR2 tirosin kinase. Vascular endothelial growth factor receptor (VEGFR) tyrosine kinases adalah target obat yang telah divalidasi secara klinis untuk terapi kanker. VEGF/VEGFR2 dianggap sebagai jalur proangiogenik paling penting untuk meningkatkan semua tahap angiogenesis termasuk permeabilitas vaskular, kelangsungan hidup sel endotelial, proliferasi, migrasi atau invasi ke jaringan sekitar, dan pembentukan tabung kapiler. Perkembangan kanker sering dikaitkan dengan ekspresi VEGF, dan jalur sinyal VEGF/VEGFR2 pada umumnya dianggap sebagai mediator utama tumor angiogenesis, sehingga VEGF/VEGFR2 merupakan sistem target untuk intervensi terapeutik pada kanker (Hoi et al., 2014).

Hasil uji in silico berupa nilai $R S$ dari $N$-(benzoil)- $N$ '-feniltiourea dan turunannya. Dari seluruh nilai $R S$ yang didapat akan ditentukan senyawa turunan $N$-(benzoil)- $N$ '-feniltiourea yang mempunyai nilai $R S$ terkecil atau diprediksi mempunyai aktivitas sitotoksik paling besar. Sebagai target reseptor pada uji in silico adalah VEGFR2, dengan kode PDB: 3WZE (Okamoto et al., 2015).

Untuk mendapatkan senyawa turunan $N$-(benzoil)- $N$ '-feniltiourea secara teoritis dapat dilakukan sintesis dengan bahan dasar turunan benzoil klorida dan mereaksikannya dengan ammonium tiosianat dan anilin. Pemilihan senyawa turunan $N$-(benzoil)- $N$ '-feniltiourea pada penelitian ini berdasarkan pada ketersediaan senyawa turunan benzoil klorida yang ada di pasaran, sehingga nantinya lebih memudahkan dalam proses sintesisnya.

\section{Bahan dan Metode}

\subsection{Alat dan bahan}


Alat yang digunakan adalah lomputer merek Lenovo, sistem operasi Windows 10, 64 bit, prosesor Intel Core i5-7200U, CPU @250 Ghz 270 Ghz, RAM 8,00 GB. Program yang digunakan meliputi Chem Bio Draw Ultra Versi 12 (CambridgeSoft), Chem Bio 3D Ultra Versi 12 (CambridgeSoft), Molegro Virtual Docker 5,5 (Molegro ApS), SMILES Translator, pkCSM, dan Protox online tool.

\subsection{Metode}

\subsubsection{Pengunduhan target protein (target reseptor VEGFR2)}

Struktur molekul target reseptor VEGFR2 dapat diunduh melalui situs protein data bank (http://www.rcsb.org/pdb/home/home.do). Penelitian ini menggunakan reseptor VEGFR2 dengan kode pdb. 3WZE, karena mengandung ligan sorafenib (kode BAX_1201). Ligan tersebut mengandung gugus urea (-NHCONH-) yang berfungsi sebagai farmakofor pada proses interaksi ligan-reseptor, dan senyawa turunan $N$-(benzoil)- $N$ '-feniltiourea mengandung gugus yang mirip yaitu -NHCSNH-, yang diharapkan juga dapat berfungsi sebagai farmakofor (Dai et al., 2008; Curtin et al., 2012, Okamoto et al., 2015).

\subsubsection{Prediksi aktivitas (Docking molekul)}

Senyawa $N$-(benzoil)- $N$ '-feniltiourea dan 23 senyawa turunannya serta senyawa pembanding hidroksiurea dan sorafenib yang akan di-docking digambar struktur molekul 2-D dengan program Chem Bio Draw Ultra versi 12, kemudian dikopi pada program Chem Bio $3 D$ Ultra versi 12 untuk membuat struktur 3-D. Setelah diukur energi minimalnya kemudian disimpan dalam bentuk mol2 \{SYBYL2(*.mol2)\}. Setelah disimpan kemudian dilakukan proses docking terhadap target reseptor VEGFR2, dengan kode PDB: 3WZE menggunakan program komputer Molegro Virtual Docker versi 5.5. Hasil yang didapat berupa nilai Rerank Score $(R S)$. $R S$ menggambarkan energi yang diperlukan dalam proses interaksi ligan-reseptor, dan dari nilai tersebut dapat diprediksi aktivitas antikanker senyawa melalui hambatan enzim tirosin kinase yang digambarkan dengan target reseptor VEGFR2 (Okamoto et al.,2015; Siswandono, 2016).

\subsubsection{Prediksi sifat fisikokimia dan toksisitas senyawa}

Prediksi sifat fisikokimia seperti: berat molekul (BM), logaritma koefisien partisi oktanol/air (Log P), jumlah ikatan antar atom yang dapat berotasi (Torsion); Hydrogen Bond Acceptors (HBA), Hydrogen Bond Donors (HBD), dan Polar Surface Activity (PSA) dilakukan dengan menggunakan pkCSM online tool. Prediksi toksisitas dari senyawa-senyawa turunan $N$-(benzoil)- $N$ '-feniltiourea dilakukan dengan menggunakan pkCSM online tool (Pires et al., 2015, Hassan et al., 2017; Saeed, et al., 2017). Sebelum dilakukan docking, 23 senyawa turunan $N$-(benzoil)- $N$ '-feniltiourea serta senyawa pembanding hidroksiurea dan sorafenib digambar struktur molekul 2-D dengan program Chem Bio Draw Ultra Versi 12, kemudian dikopi pada program Chem Bio 3D Ultra Versi 12 untuk membuat struktur 3-D, selanjutnya disimpan dalam bentuk file *.sdf atau *.pdb. Berikutnya, 23 senyawa turunan $N$-(benzoil)- $N$ 'feniltiourea serta senyawa pembanding hidroksiurea dan sorafenib, strukturnya diterjemahkan menjadi bentuk format SMILES dengan menggunakan bantuan Online SMILES Translator 
(https://cactus.nci.nih.gov/translate/). Dalam bentuk format SMILES inilah senyawa diproses menggunakan pkCSM online tool (http://biosig.unimelb.edu.au/ pkcsm/prediction) untuk memprediksi toksisitas senyawa. Untuk memprediksi toksisitas $\left(\mathrm{LD}_{50}\right)$ per oral pada rodent dan klasifikasi toksisitas senyawa berdasarkan Globally Harmonized System (GHS) digunakan Protox online tool (http://tox.charite.de/tox/) (Ruswanto dkk., 2017).

\section{Hasil dan Pembahasan}

Struktur kimia senyawa turunan $N$-(benzoil)- $N$ '-feniltiourea, senyawa pembanding hidroksiurea dan sorafenib dapat dilihat pada gambar 1 dan tabel 1 .

(a)<smiles>[R]c1ccc(C(=O)NC(=S)Nc2ccccc2)cc1</smiles>

(b)<smiles>CNC(=O)c1cc(Oc2ccc(NC(=O)Nc3ccc(Cl)c(C(F)(F)F)c3)cc2)ccn1</smiles>

(c)<smiles>NC(=O)NO</smiles>

Gambar 1. Turunan $N$-(benzoil)- $N$ '-feniltiourea (a), Sorafenib (b) dan Hidroksiurea (c)

Tabel 1. Struktur kimia senyawa-senyawa turunan $N$-(benzoil)- $N$ '-feniltiourea

\begin{tabular}{|c|c|c|c|}
\hline $\begin{array}{c}\text { No. } \\
\text { Senyawa }\end{array}$ & Posisi & $\mathbf{R}$ & Nama Senyawa \\
\hline 1. & 4 & $\mathbf{H}$ & $N$-(Benzoil)- $N$ '-feniltiourea \\
\hline 2. & 2 & $\mathbf{C H}_{3}$ & $N$-(2-Metilbenzoil)- $N$ '-feniltiourea \\
\hline 3. & 3 & $\mathbf{C H}_{3}$ & $N$-(3-Metilbenzoil)- $N$ '-feniltiourea \\
\hline 4. & 4 & $\mathrm{CH}_{3}$ & $N$-(4-Metilbenzoil)- $N$ '-feniltiourea \\
\hline 5. & 3,4 & $2 \mathrm{CH}_{3}$ & $N$-(3,4-Dimetilbenzoil)- $N$ '-feniltiourea \\
\hline 6. & 4 & $\mathrm{CH}_{2} \mathrm{CH}_{3}$ & $N$-(4-Etilbenzoil)- $N$ '-feniltiourea \\
\hline 7. & 4 & $\mathrm{C}\left(\mathrm{CH}_{3}\right)_{3}$ & $N$-(4-tert-Butilbenzoil)- $N$ '-feniltiourea \\
\hline 8. & 4 & $\mathrm{OCH}_{3}$ & $N$-(4-Metoksibenzoil)- $N$ '-feniltiourea \\
\hline 9. & 4 & $\mathrm{OCH}_{2} \mathrm{CH}_{3}$ & $N$-(4-Etoksibenzoil)- $N$ '-feniltiourea \\
\hline 10. & 4 & $\mathrm{OCH}_{2} \mathrm{CH}_{2} \mathrm{CH}_{3}$ & $N$-(4-Propoksibenzoil)- $N$ '-feniltiourea \\
\hline 11. & 2 & Cl & $N$-(2-Klorobenzoil)- $N$ '-feniltiourea \\
\hline 12. & 3 & Cl & $N$-(3-Klorobenzoil)- $N$ '-feniltiourea \\
\hline 13. & 4 & Cl & $N$-(4-Klorobenzoil)- $N$ '-feniltiourea \\
\hline 14. & 3,4 & $2 \mathrm{Cl}$ & $N$-(3,4-Dikloro-benzoil)- $N$ '-feniltiourea \\
\hline 15. & 3,5 & $2 \mathrm{Cl}$ & $N$-(3,5-Diklorobenzoil)- $N$ '-feniltiourea \\
\hline 16. & 4 & $\mathrm{Br}$ & $N$-(4-Bromobenzoil)- $N$ '-feniltiourea \\
\hline 17. & 4 & $\mathbf{F}$ & $N$-(4-Fluorobenzoil)- $N$ '-feniltiourea \\
\hline 18. & 4 & $\mathbf{C F}_{3}$ & $N$-(4-Trifluorometilbenzoil)- $N$ '-feniltiourea \\
\hline 19. & 3,4 & $2 \mathrm{CF}_{3}$ & $N$-(3,4-di-Trifluorometilbenzoil)- $N$ '-feniltiourea \\
\hline 20. & 3,5 & $2 \mathrm{CF}_{3}$ & $N$-(3,5-di-Trifluorometilbenzoil)- $N$ '-feniltiourea \\
\hline 21. & 4 & $\mathbf{N}\left(\mathrm{CH}_{3}\right)_{2}$ & $N$-(4-Dimetilaminobenzoil)- $N$ '-feniltiourea \\
\hline 22. & 3 & $\mathrm{NO}_{2}$ & $N$-(3-Nitrobenzoil)- $N$ '-feniltiourea \\
\hline 23. & 4 & $\mathrm{NO}_{2}$ & $N$-(4-Nitrobenzoil)- $N$ '-feniltiourea \\
\hline 24. & \multirow{2}{*}{\multicolumn{2}{|c|}{ Senyawa Pembanding }} & Hidroksiurea \\
\hline 25. & & & Sorafenib \\
\hline
\end{tabular}

\subsection{Prediksi sifat fisikokimia}


Prediksi in silico nilai parameter sifat fisikokimia senyawa turunan $N$-benzoil- $N$ '-feniltiourea dan senyawa pembanding dapat dilihat pada Tabel 2. Tahun 1971 Lipinski et al. telah menganalisis 2.245 obat dari data dasar World Drugs Index. Hasil analisis menyimpulkan bahwa senyawa akan sulit diabsorpsi dan permeabilitasnya rendah apabila mempunyai: berat molekulnya lebih besar 500, nilai log koefisien partisi oktanol/air $(\log \mathrm{P})$ lebih besar +5 ; ikatan-H donor (HBD), yang dinyatakan dengan jumlah gugus $\mathrm{O}-\mathrm{H}$ dan $\mathrm{N}-\mathrm{H}$, lebih besar 5; dan ikatan-H aseptor (HBA), yang dinyatakan dengan jumlah atom $\mathrm{O}$ dan $\mathrm{N}$, lebih besar 10 . Analisis tersebut dikenal sebagai hukum lima Lipinski karena semua nilai merupakan kelipatan dari angka lima. Dari tabel 2 dapat dianalisis bahwa semua senyawa turunan $N$ (benzoil)- $N$ '-feniltiourea yang diteliti memenuhi persyaratan hukum 5 Lipinski.

Tabel 2. Prediksi in silico nilai parameter-parameter sifat fisikokimia senyawa turunan $\mathrm{N}$ benzoil- $N$ '-feniltiourea dan senyawa pembanding dengan menggunakan pkCSM online tool $. \mathrm{BM}=$ Berat Molekul; LogP = logaritma koefisien partisi oktanol/air; Torsion = ikatan antar atom yang dapat berputar; HBA = Hydrogen Bond Acceptors; HBD = Hydrogen Bond Donors; PSA = Polar Surface Activity.

\begin{tabular}{cccccccc}
\hline $\begin{array}{c}\text { No. } \\
\text { Senyawa }\end{array}$ & $\mathbf{B M}$ & LogP & Torsion & HBA & HBD & PSA $\left(\mathbf{A}^{2}\right)$ & $\begin{array}{c}\text { Persyaratan } \\
\text { Hukum 5 } \\
\text { Lipinski }\end{array}$ \\
\hline 1. & $\mathbf{2 5 6 , 3 3}$ & $\mathbf{2 , 8 1}$ & $\mathbf{2}$ & $\mathbf{2}$ & $\mathbf{2}$ & $\mathbf{1 1 0 , 8 4}$ & Ya \\
2. & $\mathbf{2 7 0 , 3 6}$ & $\mathbf{3 , 1 2}$ & $\mathbf{2}$ & $\mathbf{2}$ & $\mathbf{2}$ & $\mathbf{1 1 7 , 2 0}$ & Ya \\
3. & $\mathbf{2 7 0 , 3 6}$ & $\mathbf{3 , 1 2}$ & $\mathbf{2}$ & $\mathbf{2}$ & $\mathbf{2}$ & $\mathbf{1 1 7 , 2 0}$ & Ya \\
4. & $\mathbf{2 7 0 , 3 6}$ & $\mathbf{3 , 1 2}$ & $\mathbf{2}$ & $\mathbf{2}$ & $\mathbf{2}$ & $\mathbf{1 1 7 , 2 0}$ & Ya \\
5. & $\mathbf{2 8 4 , 3 8}$ & $\mathbf{3 , 4 3}$ & $\mathbf{2}$ & $\mathbf{2}$ & $\mathbf{2}$ & $\mathbf{1 2 3 , 5 7}$ & Ya \\
6. & $\mathbf{2 8 4 , 3 8}$ & $\mathbf{3 , 3 8}$ & $\mathbf{3}$ & $\mathbf{2}$ & $\mathbf{2}$ & $\mathbf{1 2 3 , 5 7}$ & Ya \\
7. & $\mathbf{3 1 2 , 4 4}$ & $\mathbf{4 , 1 1}$ & $\mathbf{2}$ & $\mathbf{2}$ & $\mathbf{2}$ & $\mathbf{1 3 6 , 3 0}$ & Ya \\
8. & $\mathbf{2 8 6 , 3 5}$ & $\mathbf{2 , 8 2}$ & $\mathbf{3}$ & $\mathbf{3}$ & $\mathbf{2}$ & $\mathbf{1 2 2 , 3 2}$ & Ya \\
9. & $\mathbf{3 0 0 , 3 8}$ & $\mathbf{3 , 2 1}$ & $\mathbf{4}$ & $\mathbf{3}$ & $\mathbf{2}$ & $\mathbf{1 2 8 , 6 8}$ & Ya \\
10. & $\mathbf{3 1 4 , 4 1}$ & $\mathbf{3 , 6 0}$ & $\mathbf{5}$ & $\mathbf{3}$ & $\mathbf{2}$ & $\mathbf{1 3 5 , 0 5}$ & Ya \\
11. & $\mathbf{2 9 0 , 7 7}$ & $\mathbf{3 , 4 7}$ & $\mathbf{2}$ & $\mathbf{2}$ & $\mathbf{2}$ & $\mathbf{1 2 1 , 1 4}$ & Ya \\
12. & $\mathbf{2 9 0 , 7 7}$ & $\mathbf{3 , 4 7}$ & $\mathbf{2}$ & $\mathbf{2}$ & $\mathbf{2}$ & $\mathbf{1 2 1 , 1 4}$ & Ya \\
13. & $\mathbf{2 9 0 , 7 7}$ & $\mathbf{3 , 4 7}$ & $\mathbf{2}$ & $\mathbf{2}$ & $\mathbf{2}$ & $\mathbf{1 2 1 , 1 4}$ & Ya \\
14. & $\mathbf{3 2 5 , 2 1}$ & $\mathbf{4 , 1 2}$ & $\mathbf{2}$ & $\mathbf{2}$ & $\mathbf{2}$ & $\mathbf{1 3 1 , 4 5}$ & Ya \\
15. & $\mathbf{3 2 5 , 2 1}$ & $\mathbf{4 , 1 2}$ & $\mathbf{2}$ & $\mathbf{2}$ & $\mathbf{2}$ & $\mathbf{1 3 1 , 4 5}$ & Ya \\
16. & $\mathbf{3 3 5 , 2 2}$ & $\mathbf{3 , 5 8}$ & $\mathbf{2}$ & $\mathbf{2}$ & $\mathbf{2}$ & $\mathbf{1 2 4 , 7 1}$ & Ya \\
17. & $\mathbf{2 7 4 , 3 1}$ & $\mathbf{2 , 9 5}$ & $\mathbf{2}$ & $\mathbf{2}$ & $\mathbf{2}$ & $\mathbf{1 1 5 , 0 0}$ & Ya \\
18. & $\mathbf{3 2 4 , 3 3}$ & $\mathbf{3 , 8 3}$ & $\mathbf{2}$ & $\mathbf{2}$ & $\mathbf{2}$ & $\mathbf{1 2 9 , 7 0}$ & Ya \\
19. & $\mathbf{3 9 2 , 3 2}$ & $\mathbf{4 , 8 5}$ & $\mathbf{2}$ & $\mathbf{2}$ & $\mathbf{2}$ & $\mathbf{1 4 8 , 5 6}$ & Ya \\
20. & $\mathbf{3 9 2 , 3 2}$ & $\mathbf{4 , 8 5}$ & $\mathbf{2}$ & $\mathbf{2}$ & $\mathbf{2}$ & $\mathbf{1 4 8 , 5 6}$ & Ya \\
21. & $\mathbf{2 9 9 , 3 9}$ & $\mathbf{2 , 8 8}$ & $\mathbf{3}$ & $\mathbf{3}$ & $\mathbf{2}$ & $\mathbf{1 2 9 , 3 3}$ & Ya \\
22. & $\mathbf{3 0 1 , 3 2}$ & $\mathbf{2 , 7 2}$ & $\mathbf{3}$ & $\mathbf{4}$ & $\mathbf{2}$ & $\mathbf{1 2 5 , 4 9}$ & Ya \\
23. & $\mathbf{3 0 1 , 3 2}$ & $\mathbf{2 , 7 2}$ & $\mathbf{3}$ & $\mathbf{4}$ & $\mathbf{2}$ & $\mathbf{1 2 5 , 4 9}$ & Ya \\
24. & $\mathbf{7 6 , 0 5}$ & $\mathbf{- 0 , 9 6}$ & $\mathbf{0}$ & $\mathbf{2}$ & $\mathbf{3}$ & $\mathbf{2 8 , 5 4}$ & Ya \\
25. & $\mathbf{4 6 4 , 3 8}$ & $\mathbf{5 , 5 5}$ & $\mathbf{5}$ & $\mathbf{4}$ & $\mathbf{3}$ & $\mathbf{1 8 5 , 1 1}$ & Tidak \\
\hline & & & & & & & \\
\hline & & & & & & \\
\hline
\end{tabular}

\subsection{Prediksi in silico aktivitas dan toksisitas}

Hasil uji in silico docking antara senyawa-senyawa turunan $N$-(benzoil)- $N$ '-fenil-tiourea dengan target reseptor VEGFR2 (kode PDB: 3WZE) dapat dilihat pada tabel 3. Berdasarkan tabel 3 dapat dilihat bahwa nilai Rerank Score $(R S)$ dari senyawa turunan $N$-(benzoil)- $N$ 'feniltiourea berkisar antara $-92,428$ sampai $-106,332 \mathrm{kkal} / \mathrm{mol}$, dan dari nilai-nilai tersebut 
dapat diprediksi aktivitas senyawa. Semua senyawa yang diteliti mempunyai nilai $R S$ lebih kecil dibanding senyawa induk $N$-(benzoil)- $N$ '-feniltiourea, kecuali senyawa 6,7 dan 11 . Semua senyawa yang diteliti mempunyai nilai $R S$ lebih besar dari senyawa pembanding sorafenib (nilai $R S=-147,826 \mathrm{kkal} / \mathrm{mol}$ ) tetapi lebih kecil dari senyawa pembanding hidroksiurea (nilai $R S=-39,647 \mathrm{kkal} / \mathrm{mol}$ ). Senyawa no 10 dan 20 mempunyai nilai $R S$ yang paling kecil, yaitu $N$-(4-propoksibenzoil)- $N$ '-feniltiourea (nilai $R S=-106,332)$ dan $N$-(3,5-ditrifluorometilbenzoil)- $N$ '-feniltiourea $(R S=-106,231)$. Akan tetapi kedua senyawa menimbulkan efek hepatotoksik, sehingga sebagai senyawa terpilih adalah senyawa nomor 5 yaitu $N$-(3,4-dimetilbenzoil)- $N$ '-feniltiourea (nilai $R S=-105,792)$ yang tidak menimbulkan efek hepatotoksik.

Tabel 3. Prediksi in silico aktivitas dan toksisitas antikanker terhadap reseptor VEGF turunan $N$-benzoil- $N$ '-feniltiourea dan senyawa pembanding menggunakan Molegro Virtual Docker $(*)$ serta pkCSM $(* *)$ dan Protox $(* * *)$ online tool

\begin{tabular}{|c|c|c|c|c|c|c|}
\hline \multirow{2}{*}{$\begin{array}{c}\text { No. } \\
\text { Senyawa }\end{array}$} & Aktivitas & \multicolumn{4}{|c|}{ Toksisitas } & \multirow[b]{2}{*}{ Class $^{* * * *}$} \\
\hline & $\begin{array}{l}\text { Rerank } \\
\text { Score }^{*}\end{array}$ & $\begin{array}{c}\text { Ames } \\
\text { Toxicity** }\end{array}$ & $\begin{array}{c}\text { Hepato- } \\
\text { toxicity } * *\end{array}$ & $\begin{array}{c}\text { Skin } \\
\text { Sensitization** }\end{array}$ & $\begin{array}{c}L D_{50} \text { Acute }{ }^{* * * *} \\
(\mathrm{mg} / \mathrm{kg})\end{array}$ & \\
\hline 1. & $\mathbf{- 9 5 , 8 1 9}$ & Tidak & Ya & Tidak & 2850 & 5 \\
\hline 2. & $-97,021$ & Tidak & Tidak & Tidak & 2885 & 5 \\
\hline 3. & $-99,587$ & Tidak & Tidak & Tidak & 2885 & 5 \\
\hline 4. & $-99,467$ & Tidak & Ya & Tidak & 2885 & 5 \\
\hline 5. & $-105,792$ & Tidak & Tidak & Tidak & 2850 & 5 \\
\hline 6. & $-93,540$ & Tidak & Tidak & Tidak & 2885 & 5 \\
\hline 7. & $-92,428$ & Tidak & Ya & Tidak & 2885 & 5 \\
\hline 8. & $-98,577$ & Tidak & Tidak & Tidak & 2885 & 5 \\
\hline 9. & $-103,329$ & Tidak & Tidak & Tidak & 2885 & 5 \\
\hline 10. & $-106,332$ & Tidak & Ya & Tidak & 2885 & 5 \\
\hline 11. & $-95,348$ & Tidak & Tidak & Tidak & 2885 & 5 \\
\hline 12. & $-96,210$ & Tidak & Tidak & Tidak & 2885 & 5 \\
\hline 13. & $-\mathbf{9 7 , 8 3 0}$ & Tidak & Tidak & Tidak & 2885 & 5 \\
\hline 14. & $-101,838$ & Tidak & Tidak & Tidak & 2885 & 5 \\
\hline 15. & $-99,040$ & Tidak & Tidak & Tidak & 2885 & 5 \\
\hline 16. & $-98,048$ & Tidak & Tidak & Tidak & 2850 & 5 \\
\hline 17. & $-99,004$ & Tidak & Tidak & Tidak & 2885 & 5 \\
\hline 18. & $-100,209$ & Tidak & Tidak & Tidak & 2885 & 5 \\
\hline 19. & $-99,832$ & Tidak & $\mathbf{Y a}$ & Tidak & 2850 & 5 \\
\hline 20. & $-106,231$ & Tidak & Ya & Tidak & 2850 & 5 \\
\hline 21. & $-104,731$ & Tidak & Ya & Tidak & 2885 & 5 \\
\hline 22. & $-102,297$ & Tidak & Ya & Tidak & 2850 & 5 \\
\hline 23. & $-99,653$ & Tidak & Tidak & Tidak & 2850 & 5 \\
\hline 24. & $-39,647$ & Tidak & Tidak & Tidak & 5760 & 6 \\
\hline 25. & $-147,826$ & Tidak & Ya & Tidak & 800 & 4 \\
\hline
\end{tabular}

Untuk menentukan toksisitas senyawa dapat dilakukan dengan uji Ames Toxicity, metode yang digunakan secara luas untuk menilai potensi mutagenik senyawa dengan menggunakan bakteri. Hasil uji positif menunjukkan bahwa senyawa tersebut bersifat mutagenik dan oleh karena itu dapat bertindak sebagai karsinogen. Dari tabel 3 dapat dilihat bahwa semua turunan $N$-(benzoil)- $N$ '-feniltiourea dan senyawa pembanding diprediksi tidak 
menimbulkan efek mutagenik. Selain itu dari tabel 3 dapat dilihat bahwa turunan tersebut diprediksi tidak menimbulkan sensitisasi pada kulit. Untuk toksisitas per oral pada rodent ( $\mathrm{LD}_{50}$ ) dari senyawa turunan $N$-(benzoil)- $N$ '-feniltiourea, dilakukan uji in silico dan klasifikasi toksisitas senyawa berdasarkan Globally Harmonized System (GHS) dengan mengunakan Protox online tool. $\mathrm{LD}_{50}$ adalah jumlah senyawa yang diberikan yang dapat menyebabkan kematian 50\% kelompok hewan coba. Dari tabel 3 dapat dilihat bahwa semua turunan $\mathrm{N}$ (benzoil)- $N$ '-feniltiourea diprediksi mempunyai nilai $\mathrm{LD}_{50}$ pada rodent berkisar antara 2850 sampai $2885 \mathrm{mg} / \mathrm{kg}$, dan termasuk kelas toksisitas 5 GHS yang berarti senyawa mempunyai efek toksisitas akut yang rendah. Menurut tabulasi kelas toksisitas dari Hodge dan Sterner (1949) pada dosis tersebut termasuk kelas toksisitas 4, yang berarti toksisitasnya relatif rendah.

Dengan mempertimbangkan senyawa yang diprediksi mempunyai aktivitas sitotoksik paling tinggi dan tidak toksik, maka dipilih senyawa nomor 5 yaitu $N$-(3,4-dimetilbenzoil)- $N$ 'feniltiourea (nilai $R S=105,792)$ yang tidak mempunyai efek hepatotoksik serta efek toksisitas lainnya. Sehingga senyawa yang terpilih untuk bisa dilanjutkan dengan sintesis adalah $N-(3,4-$ dimetilbenzoil)- $N$ '-feniltiourea. Gambaran 3-D target reseptor VEGFR2 kode PDB: 3WZE dalam bentuk back bone dengan turunan $N$-(benzoil)- $N$ '-feniltiourea dan senyawa pembanding sorafenib dapat dilihat pada gambar 2 .

(a)

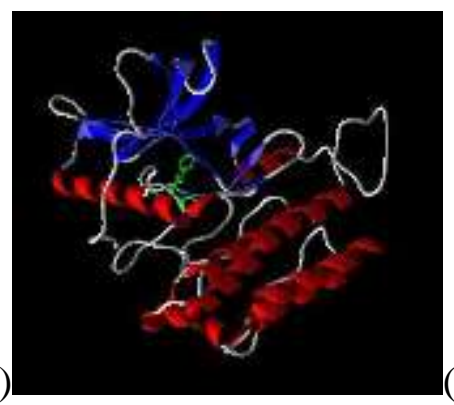

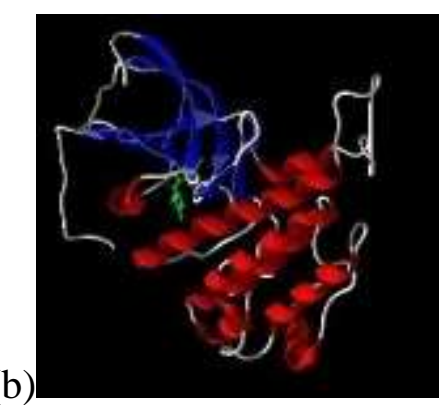

(c)

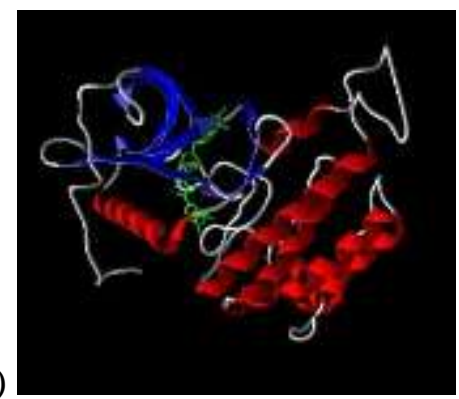

Gambar 2. Gambaran 3-D target reseptor VEGFR2 dalam bentuk backbone dengan ligan $N$-(benzoil)- $N$ '-feniltiourea (a), $N$-(3,4-dimetibenzoil)- $N$ '-feniltiourea (b) dan senyawa pembanding sorafenib (c)
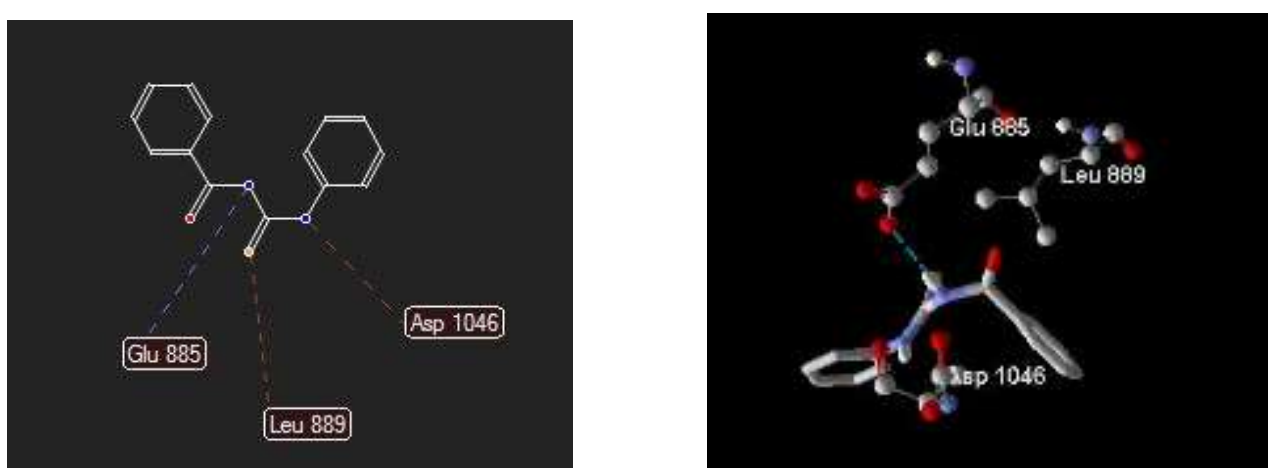

Gambar 3. Gambaran 2-D dan 3-D dari interaksi antara senyawa induk $N$-(benzoil)- $N$ 'feniltiourea, dengan target reseptor VEGFR2

Gambaran 2-D dan 3-D dari interaksi antara senyawa induk $N$-(benzoil)- $N$ '-feniltiourea, $N$-(3,4-dimetilbenzoil)- $N$ '-feniltiourea dan senyawa pembanding sorafenib dengan target 
reseptor VEGFR2 dapat dilihat pada gambar 3,4 dan 5. Asam-asam amino target reseptor VEGFR2 yang terlibat dalam interaksi dengan turunan $N$-(benzoil) $-N$ '-feniltiourea dan senyawa pembanding sorafenib dapat dilihat pada Tabel 4.
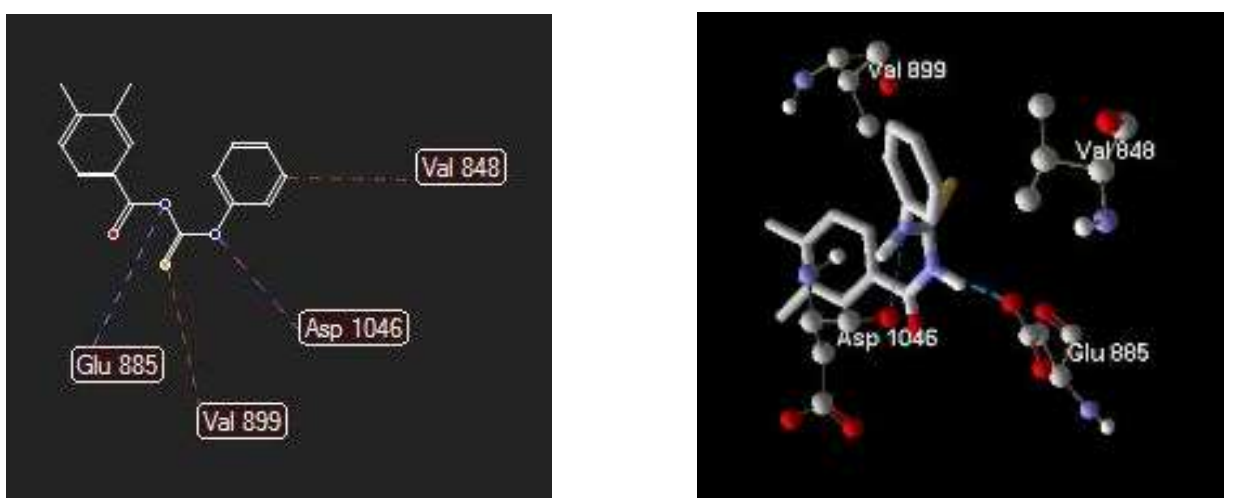

Gambar 4. Gambaran 2-D dan 3-D dari interaksi antara senyawa $N$-(3,4-dimetilbenzoil- $N$ 'feniltiourea dengan target reseptor VEGFR2
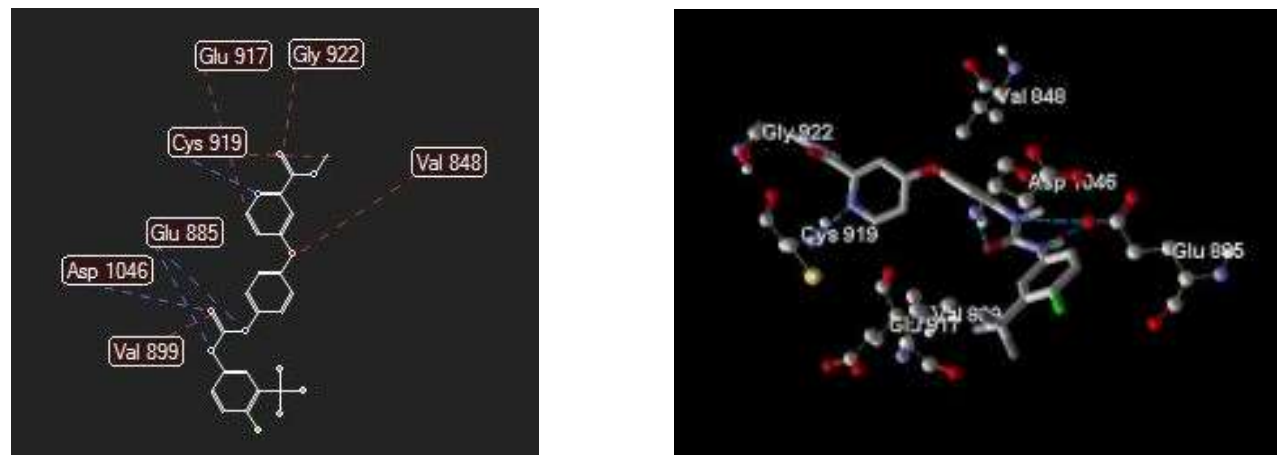

Gambar 5. Gambaran 2-D dan 3-D dari interaksi antara senyawa senyawa pembanding Sorafenib dengan target reseptor VEGFR2

Tabel 4. Asam-asam amino target reseptor VEGFR2 yang terlibat dalam interaksi dengan turunan $N$-(benzoil)- $N$ '-feniltiourea dan senyawa pembanding sorafenib.

\begin{tabular}{|c|l|c|c|}
\hline No. & \multicolumn{1}{|c|}{ Nama Senyawa } & Ikatan Hidrogen & Ikatan Sterik \\
\hline 1. & $\begin{array}{l}N \text {-(Benzoil)- } N^{\prime} \text {-fluorofenil- } \\
\text { tiourea }\end{array}$ & Glu 885 (2) & $\begin{array}{c}\text { Glu 885; Leu 889; } \\
\text { Asp 1046; }\end{array}$ \\
\hline 2. & $\begin{array}{l}N \text {-(3,4-Dimetilbenzoil)- } N \text { '- } \\
\text { feniltiourea }\end{array}$ & Glu 885; Asp 1046 & $\begin{array}{c}\text { Val 899; Glu 885; Val } \\
848 ; \text { Asp 1046 }\end{array}$ \\
\hline 3. & Senyawa pembanding Sorafenib & $\begin{array}{c}\text { Glu 885(2); } \\
\text { Cys 919; Asp 1046 }\end{array}$ & $\begin{array}{c}\text { Glu 917; Gly 922; } \\
\text { Cys 919; Val 848; Val } \\
\text { 899; Glu 885; Asp 1046 }\end{array}$ \\
\hline
\end{tabular}

Dari data nilai $R S$ (tabel 3) dapat disimpulkan bahwa ikatan antara $N$-(3,4-dimetilbenzoil)- $N$ '-feniltiourea dengan 3WZE sebagai target reseptor VEGFR2 adalah lebih stabil dibanding senyawa induk $N$-(benzoil)- $N$ '-feniltiourea, karena didukung oleh adanya ikatan hidrogen dengan asam amino Glu 885; Asp 1046, dan ikatan sterik dengan asam amino Val 899; Glu 885; Val 848 dan Asp 1046, sedangkan senyawa induk hanya mempunyai dua ikatan 
hidrogen dengan Glu 665 serta ikatan sterik dengan asam amino Leu 889; Asp 1046 dan Glu 885. Senyawa yang diteliti diprediksi mempunyai aktivitas sitotoksik yang lebih rendah dari senyawa pembanding yang mempunyai ikatan hidrogen dengan asam-asam amino Glu 885 (2); Asp 1046 dan Cys 919 serta ikatan sterik dengan asam-asam amino Glu 917; Gly 922; Cys 919; Val 848; Val 899; Glu 885; Asp 1046.

\section{Kesimpulan}

Dari hasil penelitian pemodelan molekul ini dapat disimpulkan bahwa senyawa $N-(3,4-$ dimetilbenzoil)- $N$ '-feniltiourea paling layak untuk disintesis dan dilanjutkan dengan uji aktivitasnya secara in vitro dan in vivo, karena diprediksi akan mempunyai aktivitas paling baik dan tidak mempunyai efek hepatotoksik serta efek toksisitas lainnya.

\section{Ucapan Terimakasih}

Terima kasih saya sampaikan kepada Prof. Dr. Siswandono, Apt., M.S. yang mempunyai lisensi program Molegro Virtual Docker.

\section{Daftar Pustaka}

Curtin, M.L., Frey, R.R.,Heyman, H.R., Soni, N.B., Marcotte, P.A., Pease, L.J.,Glaser, K.B., Magoc, T.J., Tapang, P., Albert, D.H., Osterling, D.J., Olson, A.M.,Bouska, J.J., Guan, Z., Preusser, L.C., Polakowski, J.S., Stewart, K.D., Tse, C.,Davidsen, S.K., Michaelides, M.R., 2012. Thienopyridine ureas as dual inhibitors of the VEGF and Aurora kinase families. Bioorganic \& Medicinal Chemistry Letters, 22, pp. 3208-3212.

Dai, Y., Hartandi, K., Soni, N.B., Pease, L.J., Reuter, D.R., Olson, A.M., Osterling, D.J., Doktor, S.Z., Albert, D.H., Bouska, J.J., Glaser, K.B., Marcotte, P.A., Stewart, K.D., Davidsen, S.K., and Michaelides, M.R., 2008. Identification of aminopyrazolo-pyridine ureas as potent VEGFR-PDGFR multitargeted kinase inhibitors, Bioorganic \& Medicinal Chemistry Letters, 18,pp. 386-390.

Hardjono, S., 2012. Modifikasi Struktur 1-(Benzoiloksi)urea dan Hubungan Kuantitatif Struktur-Aktivitas Sitotoksiknya, Universitas Airlangga, Disertasi, Surabaya.

Hardjono, S.,Siswandono, Purwanto, Darmanto, W., 2016. Quantitative Structure-Cytotoxic Activity Relationship 1-(Benzoyloxy)urea And Its Derivative, Current Drug Discovery Technollogy, Vol. 13, No.2, pp. 101-108.

Hassan, M., Abbas, Q., Ashraf, Z., Moustafa, A.A., Seo, S-Y, 2017. Pharmacoinformatics exploration of polyphenol oxidases leading to novel inhibitors by virtual screening and molecular dynamic simulation study, Computational Biology and Chemistry, 68, pp. 131-142.

Hinchliffe, A., 2008. Molecular Modeling for Beginners. $2^{\text {nd }}$ ed., Chichester: John Wiley and Sons Ltd.

Hodge, H.C. and Sterner, J.H., 1949, Tabulation of Toxicity Classes, Journal American Industrial Hygiene Association Quarterly, Vol. 10, Issue 4, pp. 93-96. Published online: 09 Jan 2008. 
Hoi, P.M.,Li, S, Vong, C.T.,Tseng, H.H.L., Kwan, Y.W., Lee, S.M-Y., 2015. Recent advances in structure-based drug design and virtual screening of VEGFR tyrosine kinase inhibitors. Methods, 71, pp. 85-91.

Jensen, F., 2007. Introduction to Computational Chemistry, $2^{\text {nd }}$ Ed, Chichester: John Wiley \& Sons Ltd.

Li K and Luo J, 2010. The role of SIRT1 in tumorigenesis, North American Journal of Medical Sciences (Boston), 4(2), pp.104-106.

Lipinski, C.A., Lombardo, F., Dominy, B.W., Feeney, F.J., 1997. Experimental and computational approaches to estimate solubility and permeability in drug discovery and development settings, Advanced Drug Delivery Reviews, 23, 3-25.

Nasyanka, A.L., 2017, Hubungan Kuantitatif Struktur Aktivitas Sitotoksik dari Senyawa Induk $N$-Benzoil- $N$ '-(4-fluorofenil)tiourea dan Turunannya Terhadap Cell Line MCF7, Universitas Airlangga, Tesis, Surabaya.

Okamoto K., Kawada, M.I., Jestel A., Konig K., Funahashi Y., Matsushima T., Tsuruoka A., Inaoue A., and Matsui J., 2015. Distinct Binding Mode of Multikinase Inhibitor Lenvatinib Revealedby Biochemical Characterization, ACS Medicinal Chemistry Letters, 6, pp. 89 -94.

Pires, D.E.V., Blundell, T.L., and Ascher, D.B., 2015. pkCSM Predicting Small-Molecule Pharmacokinetic and Toxicity Properties Using Graph-Based Signatures, Journal of Medicinal Chemistry, 58, pp.4066-4072.

Ruswanto, Siswandono, Richa,M., Tita, N., Tresna, L.,2017. Molecular Docking of 1Benzoyl-3-methylthiourea as Anti Cancer Candidate and Its Absorption, Distribution, and Toxicity Prediction, Journal of Pharmaceutical Science and Research, Vol. 9(5), pp. 680-684.

Saeed, A., Rehman, S., Channar, P.A., Larik, F.A., Abbas, Q., Hassan, M., Raza, H., Flörke, U., Seo, S-Y., 2017. Long chain 1-acyl-3-arylthioureas as jack bean urease inhibitors, synthesis, kinetic mechanism and molecular docking studies, Journal of the Taiwan Institute of Chemical Engineers, Vol. 77, pp. 54-63.

Schlick, T., 2010. Molecular Modeling and Simulation, An Interdisciplinary Guide. $2^{\text {nd }}$ ed., New York: Springer Science+Business Media.

Siswandono, 2014. Pengembangan Obat Baru, Edisi Pertama, Surabaya: Airlangga University Press.

Siswandono (ed.), 2016. Kimia Medisinal I, Edisi Kedua, Surabaya: Airlangga University Press.

Usui, T., Ban, H.S., Kawada, J., Hirokawa, T., and Nakamura, H., 2008. Discovery of indenopyrazoles as EGFR and VEGFR-2 tyrosine kinase inhibitors by in silico highthroughput screening. Bioorganic \& Medicinal Chemistry Letters, 18, pp. 285-288.

World Health Organization and International Agency for Research on Cancer (IARC), 2012, GLOBOCAN 2012: Estimated cancer incidence, mortality, and prevalence worldwide in 2012.Diakses melalui http://globocan.iarc.fr/Pages/fact_sheets_ population.aspx pada tanggal 1 Mei 2017. 